\title{
Nominal Wage FleXIBILITY, WaGe INDEXATION AND MONETARY UNION
}

\author{
LARS CALMFORS \\ ÅSA JOHANSSON
}

CESIFO WORKING PAPER No. 761

CATEGORY 4: LABOUR MARKETS

August 2002

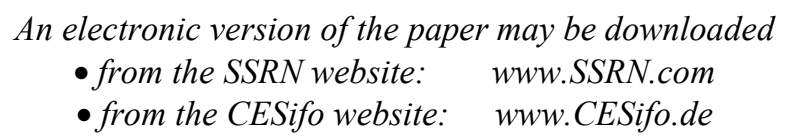




\title{
NOMINAL WAGE FLEXIBILITY, WAGE INDEXATION AND MONETARY UNION
}

\begin{abstract}
Membership in a monetary union implies stronger incentives for nominal wage flexibility in the form of wage indexation and shorter contract length than nonmembership. For example, entry into a monetary union may cause a move from a non-indexation to an indexation equilibrium. But more wage flexibility is only an imperfect substitute for an own monetary policy. It is possible that an increase in wage flexibility is welfare-decreasing because of the accompanying rise in price variability. The interaction between wage setting and central bank behaviour may result in either multiple equilibria or a unique full-indexation equilibrium.
\end{abstract}

JEL Classification: E24, E32, F33, F41.

Keywords: nominal wage flexibility, wage indexation, monetary union, asymmetric shocks.

Lars Calmfors
Institute for International Economic
Studies
10691 Stockholm
Sweden
lcalmfors@iies.su.se

Lars Calmfors

Studies

Sweden 


\section{Introduction}

Asymmetric shocks play an important role in the theory of optimal currency areas. It is a common hypothesis that macroeconomic variability will increase with the formation of a monetary union because of the loss of national monetary policy as a stabilisation tool. This aspect has featured prominently in the discussion on the Economic and Monetary Union (EMU) in Europe. The effects of asymmetric shocks in various monetary regimes have recently been analysed by e.g. Coricelli et al. (2000) and Lane (2000) in models with nominal wage rigidity. A key issue is, however, how monetary union will affect the incentives for other adjustment mechanisms that can substitute for national monetary policy. We analyse whether increased nominal wage flexibility can play such a role. More precisely, we ask the conditional question: if membership in a monetary union tends to increase macroeconomic variability, to what extent will nominal wages become more flexible? This issue has so far been dealt with mainly in reduced-form models of labour market reform (see e.g. Sibert and Sutherland, 2000; Calmfors, 2001; or Bentolila and Saint-Paul, 2001).

Our starting point is that the need for stabilisation policy arises from wage inflexibility. There are several ways of thinking about such rigidity. A first set of explanations emphasises general difficulties of changing nominal wages: the reasons may be social norms against wage cuts (Akerlof and Yellen, 1990; Bewley, 1998), menu costs (Blanchard and Kioyotaki, 1987; Ball and Romer, 1991), that past nominal wage levels act as fall-back positions in new bargaining (Holden, 1997) or that insiders have a small interest in wage flexibility, as employment variations fall largely on outsiders (Gottfries, 1992). A second approach stresses the existence of predetermined contract periods, the length of which depends on a trade-off between contract and variability costs (Gray, 1978; Ball, 1987). A third approach focuses on the incentives for contingent rules, viz. indexation, as a way to achieve nominal wage flexibility during contract periods (Gray, 1976; Blanchard 1979; Ball, 1988).

Our interest is in how monetary union is likely to affect nominal wage flexibility in a setting like the European one, where it may be reasonable to assume that there are no serious problems of inflation bias because central banks have been made independent. The focus is on how monetary union (subsequently EMU for short) affects the incentives to index wages, but we also analyse the effect on contract length. As different types of nominal wage rigidity depend on similar factors, this analysis highlights how wage flexibility in general is likely to be influenced. But the analysis of wage indexation and contract length 
is also interesting in its own right, as we want to understand in general which conditions are conducive to various contract arrangements. For example, in the 1980s and early 1990s, indexation schemes were abolished in some European countries. One important question is whether the EMU might reverse this trend. This possibility is suggested by the fact that indexation clauses have become more common in Spain and reintroduced in Finland after these countries joined the EMU (OECD, 2001; Inkomstpolitiskt avtal, 2001). Also, two other EMU members, Belgium and Luxemburg, never abolished their earlier indexation schemes.

The theory of wage indexation originated with Gray (1976) and Fischer (1977). It has focused on the incentives to stabilise employment. With nominal demand shocks, wage setters prefer full indexation, as this stabilises the real wage and thus also employment. In the case of real supply shocks, wage setters want lower indexation, possibly zero, because this leads to real wage changes that completely offset the direct employment effects of the shocks. When both types of shocks occur, partial indexation is optimal. Other work raised the possibility of fixed costs of indexation, which might imply that the stabilisation gains are not large enough to motivate indexation (Gray, 1978; Ball, 1988). Some of the work has also emphasised the similarity between the problem of choosing the degree of indexation and that of choosing contract length (Gray, 1978; Ball, 1988).

Later work by e.g.Van Hoose and Waller (1991), Ball and Cecchetti (1991), Waller and Van Hoose (1992), Milesi-Ferretti (1994), Walsh (1995), Hutchison and Walsh (1998), and Heinemann (1999) has analysed the interaction between wage indexation and monetary policy. The earlier insight that the incentives for wage indexation are weaker the larger is supply-side variability remains. This may help explain the abolishment of earlier indexation schemes in some European countries in the 1980s, after they were hit by serious supply shocks.

Most of the literature has modelled closed economies, although there are exceptions, such as Flood and Marion (1982), Aizenman (1985), Aizenman and Frenkel (1995), and Bryson et al. (1998). Leichter (1998) analysed the impact of monetary union on the incentives for indexation and concluded that they would be strengthened. The reason is that a common monetary policy does not stabilise country-specific supply shocks; hence the cost of indexation in terms of reducing the effectiveness of monetary policy to stabilise supply shocks becomes lower. The analysis assumes that all countries produce a homogenous good, so that no real exchange rate changes occur.

We develop the open-economy aspects of the analysis of nominal wage flexibility by explicitly distinguishing between three rather than two types of shocks: real supply, real 
demand and nominal exchange rate shocks. ${ }^{1}$ This richer modelling of shocks is important for a proper comparison between membership and non-membership in a monetary union. We also emphasise the objective of stabilising the real consumption wage more than is usually done. $^{2}$

A key conclusion is that EMU membership strengthens the incentives for wage indexation. In the presence of indexation costs, wage setters may choose non-indexation outside the EMU but indexation inside. Similarly, EMU membership reduces contract length. But more nominal wage flexibility inside than outside the EMU is at best an imperfect substitute for a national monetary policy. Increased nominal wage flexibility may even be socially undesirable: although employment and real wage variability is reduced, the welfare gain from this could be outweighed by the welfare loss from more price variability. Socially optimal indexation is always lower than equilibrium indexation in our model. Hence, the more centralised the decisions on indexation, the less likely it is. This conclusion squares well with the fact that the abolishment of indexation in, for example Denmark, Italy and the Netherlands, was associated with government interventions.

A novel feature of our analysis is that there are multiple indexation equilibria under some circumstances, whereas there is only a unique full-indexation equilibria under other circumstances.

Section 2 sets up the basic model. Section 3 derives equilibrium indexation inside and outside the EMU in the absence of indexation costs. Section 4 analyses the likelihood of indexation versus non-indexation equilibria when there are indexation costs. Section 5 discusses the social welfare consequences of indexation. Section 6 shows that contract length can be analysed in a similar way as indexation. Section 7 concludes.

\section{The model}

We employ a stylized model of a small open economy, which produces a domestic good and consumes both this domestic good and a foreign good. The foreign-currency price of the foreign good is exogenous. As our interest is in how asymmetric shocks affect wage setting, we neglect common shocks and focus on domestic productivity and demand shocks, as well as on exchange rate shocks (which only occur when the economy is outside

\footnotetext{
${ }^{1}$ Bentolila and Saint-Paul (2001) analysed inter alia how nominal wage flexibility is affected by EMU membership, but their results are hard to interpret because no distinction is made between nominal exchange rate and real demand shocks.

${ }^{2}$ Ball and Cecchetti (1991), Milesi-Feretti (1994), Hutchison and Walsh (1998), and Heinemann (1999) do, however, analyse real-wage objectives as well.
} 
the EMU).

The model has the following time structure. Wage contracts are concluded before the realisations of all shocks. Outside the EMU, the domestic central bank acts after demand and supply shocks, but before exchange rate shocks. These assumptions ensure that there is scope for stabilisation policy at the same time as they allow for exchange rate volatility that cannot be countered by monetary policy.

\subsection{The structure of the economy}

Output is produced by a continuum of identical perfectly competitive firms indexed on the interval $[0,1]$. Firm $i$ has a Cobb-Douglas production function

$$
y_{i}=a l_{i}+\theta
$$

where $y_{i}$ is output, $l_{i}$ is employment, $\theta$ is a productivity shock, which is common to all firms, and $0<a<1$ is the elasticity of output with respect to employment. All lower-case variables are logs.

Profit maximization gives employment in firm $i$ as

$$
l_{i}=-\frac{1}{1-a}\left(w_{i}-p-\ln a-\theta\right)
$$

where $w_{i}$ is the nominal wage in the firm and $p$ is the price of the domestic good.

A wage contract in a firm has two components. It determines: $(i)$ a nominal base wage $w_{i 0}$; and $(i i)$ an indexation parameter, $b_{i}$, which indexes the nominal wage to unexpected changes in the consumer price index $(\mathrm{CPI}), p_{c}$. This gives

$$
w_{i}=w_{i 0}+b_{i}\left(p_{c}-p_{c}^{e}\right)
$$

where the $e$ superscript indicates expected variables. It is well-known that, in the absence of contract costs, such a wage contract is not optimal: the first-best solution would be to index wages to the shocks themselves (Blanchard, 1979). However, real-world contingent contracts usually have the above form. A plausible reason is that indexation to the CPI may offer a second-best solution: contract costs are held down because of the simplicity of the indexation scheme and because CPI changes are easy to verify. ${ }^{3}$

\footnotetext{
${ }^{3}$ Because of its theoretical underpinnings as a measure of the cost of living, the CPI is widely regarded as the most reliable price index. Substantial resources are usually invested in the construction of it, and in many countries there are formalised procedures for how the decisions on index numbers should be taken (often in specific index boards).
} 
A local wage setter has the quadratic loss function

$$
L_{i}^{T U}=l_{i t}^{2}+\gamma\left(w_{i}-p_{c}-\phi\right)^{2}+\lambda p_{c}^{2}
$$

A local wage setter thus wants to minimise the fluctuations of employment and the real consumption wage around target levels, which we set to zero for employment and to $\phi$ for the real consumption wage. Wage setters also experience disutility from variations in the CPI ${ }^{4} \gamma$ and $\lambda$ are the relative weights for real wage and price variability, respectively.

Aggregate supply is $y^{S}=\int_{0}^{1} y_{i} d i$. Aggregate demand for the domestic good, $y^{D}$, depends on the real exchange rate, $e-p$, where $e$ is the nominal exchange rate, and on a stochastic real demand shock, $v . \beta$ is the elasticity of demand for domestic goods with respect to the real exchange rate. Hence, we have:

$$
y^{D}=\beta(e-p)+v .
$$

The CPI is

$$
p_{c}=\alpha p+(1-\alpha) e,
$$

where $\alpha$ is the weight of domestic goods in consumption.

Outside the EMU, monetary policy is set by the domestic central bank. Like Bentolila and Saint-Paul (2001), we assume that the intermediate target of the central bank is the exchange rate. The bank tries to achieve an exchange rate that minimises its loss function. But the actual exchange rate varies around the desired level due to exchange rate shocks. We thus have

$$
e=e^{C B}+\xi
$$

where $e^{C B}$ is the desired exchange rate for the central bank, which we shall refer to as its "policy instrument", and $\xi$ is a nominal shock. The central bank has the loss function

$$
L^{C B}=\left(l-l^{*}\right)^{2}+\lambda p_{c}^{2},
$$

where $l=\int_{0}^{1} l_{i} d i$ and $l^{*}$ is the bank's employment target. We set $l^{*}=l^{e}$, i.e. the bank's employment target is equal to the expected employment level. This rules out any inflation bias of monetary policy, which we find a reasonable characteristic of central bank behaviour in today's Western Europe.

The three shocks are all i.i.d. with zero means and known variances: $\sigma_{\theta}^{2}, \sigma_{v}^{2}$, and $\sigma_{\xi}^{2}$.

\footnotetext{
${ }^{4}$ If we set the preceding period's CPI level to zero, our formulation is equivalent to entering inflation into the loss function.
} 


\subsection{Price determination}

By equating aggregate supply and demand, and using the wage formula (3), we obtain:

$$
\begin{aligned}
p= & \frac{(1-a) \beta}{a+\beta(1-a)} e+\frac{a}{a+\beta(1-a)}\left(w_{0}-\ln a\right)+\frac{a b}{a+\beta(1-a)}\left(p_{c}-p_{c}^{e}\right) \\
& +\frac{(1-a)}{a+\beta(1-a)} v-\frac{1}{a+\beta(1-a)} \theta,
\end{aligned}
$$

where $w_{0}=\int_{0}^{1} w_{i 0} d i$ is the aggregate base wage and $b=\int_{0}^{1} b_{i} d i$ is aggregate indexation.

From (9) and (6), we obtain:

$$
p_{c}-p_{c}^{e}=\frac{(1-\alpha) a+(1-a) \beta}{a+\beta(1-a)-a b \alpha}\left(e-e^{e}\right)+\frac{\alpha(1-a) v}{a+\beta(1-a)-a b \alpha}-\frac{\alpha \theta}{a+\beta(1-a)-a b \alpha} .
$$

\subsection{Monetary policy}

Inside the EMU, the exchange rate is irrevocably fixed and assumed to equal the expected exchange rate outside the EMU. Outside the EMU, the central bank sets its monetary policy instrument $e^{C B}$ so as to minimise the expectation of the loss function (8) subject to $(2),(3),(6),(7),(9),(10)$ and the definitions of $w_{0}, b$, and $l$. When the bank acts, it knows the realisations of $w_{0}, b, \theta$ and $v$, and responds to them in a discretionary way. ${ }^{5}$

From the FOC we can derive the policy response function of the central bank:

$$
e^{C B}=q+H \theta+K v,
$$

where $q$ is an uninteresting constant and $H$ and $K$ are given in Appendix A.1. $H$ and $K$ cannot be unambigously signed, but for all the parameter values we use $H>0$ and $K<0$.

Consider first a negative demand shock. $K<0$ then implies that monetary policy is eased with the aim of depreciating the currency. This can be understood as follows. With a constant exchange rate, the output price falls. This causes both employment and the CPI to fall. The bank responds by easing monetary policy. The optimal response is to limit the fall in employment by allowing a rise in the CPI.

Consider then a negative supply shock. $H>0$ then implies that monetary policy is tightened in order to appreciate the currency. The effects on employment and the CPI

\footnotetext{
${ }^{5}$ The assumption is thus that the bank cannot precommit to a policy rule, which would allow it to act as a Stackelberg leader, taking the responses of wage setters into account.
} 
depends on parameter values. If $\beta$ is sufficiently large, the optimal response of the bank is to allow a rise in the CPI and a fall in employment in this case, too. ${ }^{6}$

\section{$3 \quad$ Wage decisions with no indexation costs}

\subsection{EMU membership}

We first analyse wage contracts with EMU membership. We look at a symmetric Nash equilibrium where each local wage setter chooses $w_{i 0}$ and $b_{i}$, taking the aggregate base wage, $w_{0}$, and aggregate indexation, $b$, as given. The optimisation is made by minimising the expectation of (4) subject to (2), (3), (6), (9), (10) and the assumption that $e=e^{e}=q$. Note that inflation considerations do not matter for indexation, because the path of the $\mathrm{CPI}$ is exogenous to a local wage setter. Equilibrium indexation is:

$$
b=\frac{(1-\beta)+\left((1-a)+\gamma \alpha(1-a)^{3}\right) \sigma_{1}+\gamma \alpha(1-a)}{\alpha+\left(\alpha(1-a)+\gamma \alpha(1-a)^{3}\right) \sigma_{1}+\gamma \alpha(1-a)}
$$

where $\sigma_{1}=\sigma_{v}^{2} / \sigma_{\theta}^{2}$ is the ratio between the variance of the demand shock and the variance of the supply shock.

Equation (12) shows the standard property that an increase in the relative variability of demand, $\sigma_{1}$, increases indexation. This follows from the objective to stabilise employment. Consider the extreme case when $\alpha=1$ (only domestic goods are consumed), $\beta=1$ (a unitary elasticity of demand with respect to the real exchange rate), and $\gamma=0$ (wage setters do not care about the real consumption wage). Then $b=(1-a) \sigma_{1} /\left(1+(1-a) \sigma_{1}\right)$, which is the expression for a closed economy derived by Gray (1976). Hence $b=0$, if there are only supply shocks $\left(\sigma_{v}^{2}=0\right)$. In this case, according to $(9), d p=-d \theta$. As employment in each firm depends on $w_{i}-p-\theta$, a supply shock hence causes a change in the real product wage, $w_{i}-p$, that exactly offsets the direct employment effect of the shock. With only demand shocks $\left(\sigma_{\theta}^{2}=0\right), b=1$ : in this case equally large price and wage changes keep the real product wage, and thus also employment, constant. When there are both types of shocks, there is partial indexation.

In the general case when $0<\alpha<1, \beta>0$ and $\gamma>0$, we have that $(1-\beta) / \alpha \leq$ $b \leq 1 / \alpha$. Some indexation is then optimal also if there are only supply shocks. ${ }^{7}$ As $b=1$ stabilises the real consumption wage completely, indexation is closer to unity, the larger

\footnotetext{
${ }^{6}$ The precise condition is $\beta>1-\alpha$. See Van Hoose and Waller (1991), Waller and Van Hoose (1992), Walsh (1995), Hutchison and Walsh (1998), and Leichter (1998) for similar analyses.

${ }^{7}$ If $\beta>1$, the optimal indexation could be negative.
} 
the weight for the real wage, $\gamma$. Indexation may also be greater than unity. This happens with a small weight for the real wage and large relative demand variability. The reason is that domestic output makes up only part of the CPI. If a demand shock raises the output price by one percent, the percentage rise of the CPI is $\alpha$; hence the indexation parameter must be $1 / \alpha$ if the money wage is also to rise by one percent so as to leave the real product wage constant.

\subsection{Non-membership in the EMU}

As in the EMU case, each wage setter sets $w_{i 0}$ and $b_{i}$ so as to minimise the expectation of (4). But wage setters now also take the domestic central bank's response function (11) and the possibility of exchange rate shocks into account. The FOCs now give:

$$
b_{i}=\frac{A+B \sigma_{1}+C \sigma_{2}}{\left(1+\gamma(1-a)^{2}\right)\left(D+E \sigma_{1}+F \sigma_{2}\right)}+\frac{\gamma(1-a)^{2}}{1+\gamma(1-a)^{2}}=f(b),
$$

where in addition to earlier explained symbols $\sigma_{2}=\sigma_{\xi}^{2} / \sigma_{\theta}^{2}$. A, B, C,D,E, and $F$ are all functions of $b$ and are given in Appendix A.2.

Setting $b_{i}=b$ in (13) gives an equation for aggregate indexation. Indexation now depends on the relative importance of the three shocks: the ratio between the variances of the demand and the supply shocks, $\sigma_{1}$, and the ratio between the variances of the exchange rate and supply shocks, $\sigma_{2}$. The equation for aggregate indexation is a fifthdegree polynomial in $b$. Two possible sets of solutions are illustrated in Figure 1 by the intersections of the 45-degree line and the $f(b)$ curves, which represent the RHS of (13).

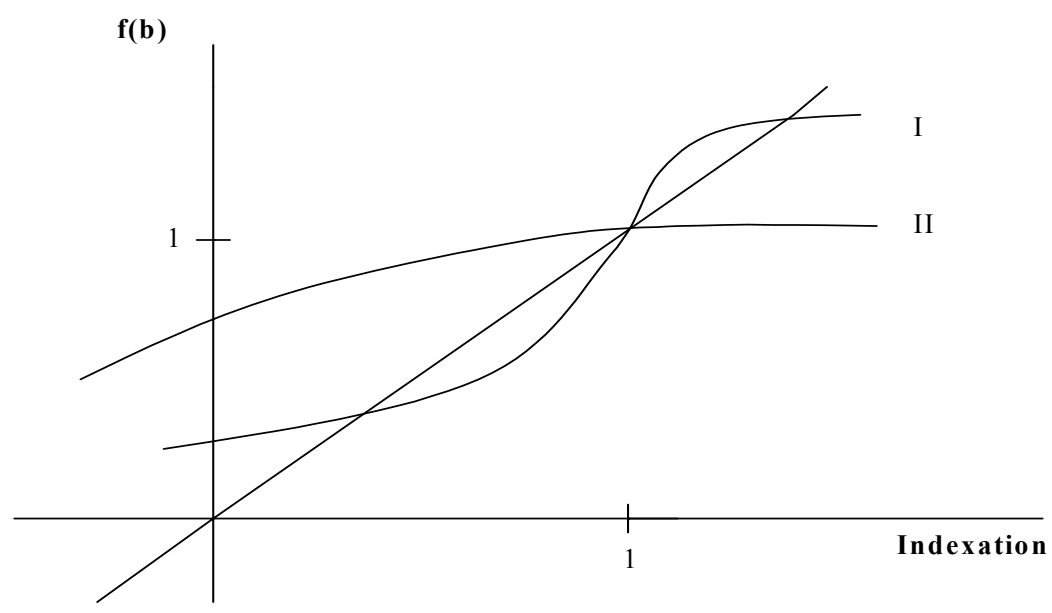

Figure 1: Equilibrium indexation inside the EMU

Curve I illustrates a case with three equilibria: there is then usually one with $0<b<1$, always one with $b=1$, and usually one with $b>1$. Curve II shows a case where $b=1$ is 
the only equilibrium. The $b=1$ equilibrium can be explained as follows. With $b=1$, the central bank cannot affect the real product wage, $w-p$, as an exchange rate change leads to equal changes in the output price and the money wage. This makes the bank unable to influence employment. The best it can do is then to focus solely on price stability. Hence, the central bank offsets completely all effects on the CPI of real demand and supply shocks. All variations in the CPI are therefore due to exchange rate shocks. More precisely $p_{c}=\xi$, as shown in Appendix A.3. $b=1$ is a Nash equilibrium because the best response of each local wage setter is then to set $b_{i}=1$, as this insulates both the real consumption wage and employment from exchange rate shocks. This does not stabilise employment in the case of demand or supply shocks, but there is no point in trying to do so through indexation, as these shocks do not move the CPI. ${ }^{8}$

With curve I, the $0<b<1$ and $b>1$ equilibria in Figure 1 are both (dynamically) stable, whereas the $b=1$ equilibrium is unstable. ${ }^{9}$ In these cases, social welfare is the highest in the $0<b<1$ equilibrium. When there is only one equilibrium with $b=1$, as with curve II, this equilibrium is always stable.

\subsection{Numerical examples}

As general analytical results are difficult to derive, we resort to numerical examples. Throughout, we assume $a=\alpha=0.7$, which are relevant values for most EU countries (Walsh, 1995; Walsh and Hutchison, 1998; Lane, 2001). We set $\beta=0.5$ in most examples, which is consistent with conventional estimates of export and import elasticities, as reported in e.g. Krugman and Obstfeld (2000), ${ }^{10}$ but we also report computations with $\beta=1$ as an example of a possible future situation with more integrated markets than today. As to $\lambda$, Broadbent and Barro (1997) found a weight of inflation in the central bank's loss function of 3 . We regard lower values of $\lambda$ as more plausible, as we find it hard to believe in such a high weight on price stability in a credible low-inflation regime such as we have assumed. ${ }^{11}$ However, we vary $\lambda$ between 1 and 3 in our examples.

\footnotetext{
${ }^{8}$ The possibilities of multiple equilibria and a single $b=1$ equilibrium are not specific to our open economy model. Similar results are obtained in closed-economy models with an optimising central bank if there is a nominal shock that policy cannot counter. This has not been recognised generally. See, however, Heinemann (1999) for an exception.

${ }^{9}$ Stability is then defined as local stability around the equilibrium if we impose a dynamic adjustment process according to which $\dot{b}_{i}=\phi\left(f(b)-b_{i}\right)$, where $\phi>0$. A necessary condition for such stability is that the $f(b)$-curve is less sloped than the 45-degree line around the equilibrium.

${ }^{10}$ With export and import shares in GDP of 0.3 , export and import elasticities of 0.8 correspond to $\beta=0.48$. $\beta=0.5$ is also the assumption made in Lane $(2000)$.

${ }^{11}$ If the employment goal equals equilibrium employment, so that there is no inflation bias, then there is no reason to appoint a conservative central banker in the Rogoff (1985) sense. One should then expect
} 
As to the weight of the real wage in the wage setters' loss functions, $\gamma=1$ is our main assumption, but we also experiment with larger weights. We look at several shock patterns, but they are all chosen so as to give larger macroeconomic variability inside the EMU than outside when nominal wages are rigid (zero indexation), so that there is a potential stabilisation cost of EMU membership. ${ }^{12}$ In our tables, the three shocks have equal variances in the first row. In the second row, the variance of the supply shock is twice the variance of the other shocks. In the third row, the variance of the demand shock is twice the variance of the other shocks, and in the fourth row the variance of the exchange rate shock is twice the variance of the other shocks.

Tables 1 and 2 give equilibrium indexation under various assumptions. When there are multiple equilibria outside the EMU, we focus on the partial-indexation equilibrium. This is regarded as a focal point both because it has reasonable characteristics (stability and the highest social welfare) and because partial indexation schemes have been the most common in practice. In a few cases, there are deviations from the described pattern. We then report the stable equilibrium with the lowest indexation, which is also the one with the highest social welfare.

\begin{tabular}{|c|c|c|c|c|c|c|c|c|}
\hline & Inside the EMU & \multicolumn{6}{|c|}{ Outside the EMU $^{a}$} \\
\hline & $\beta=1$ & $\beta=0.5$ & \multicolumn{3}{|c|}{$\beta=1$} & \multicolumn{3}{|c|}{$\beta=0.5$} \\
\hline Variances & & & $\lambda=1$ & $\lambda=2$ & $\lambda=3$ & $\lambda=1$ & $\lambda=2$ & $\lambda=3$ \\
\hline$\sigma_{1}=\sigma_{2}=1$ & 0.46 & 0.90 & 0.52 & $0.57^{c}$ & $1^{b}$ & $0.54^{c}$ & $1^{b}$ & $1^{b}$ \\
\hline$\sigma_{1}=\sigma_{2}=1 / 2$ & 0.36 & 0.85 & 0.34 & 0.24 & 0.21 & 0.37 & $1^{b}$ & $1^{b}$ \\
\hline$\sigma_{1}=2, \sigma_{2}=1$ & 0.62 & 0.99 & 0.48 & 0.48 & $1^{b}$ & 0.25 & $0.19^{c}$ & $1^{b}$ \\
\hline$\sigma_{1}=1, \sigma_{2}=2$ & 0.46 & 0.90 & $0.79^{c}$ & $1^{b}$ & $1^{b}$ & $1^{b}$ & $1^{b}$ & $1^{b}$ \\
\hline $\begin{array}{l}\text { a) Unless stated otherwise there are three equilibria: } 0<\mathrm{b}<1, \mathrm{~b}=1 \text { and } \mathrm{b}>1 \text {. The table gives the } \\
\text { stable equilibrium with the lowest indexation. } \\
b) \text { This is the only equilibrium. It is stable. } \\
\text { c) There are three equilibria: two with } 0<\mathrm{b}<1 \text { and one with } \mathrm{b}=1 .\end{array}$ \\
\hline
\end{tabular}

Table 1: Equilibrium indexation when $\gamma=1$

the weight of inflation in the central bank's preference function to equal the "true" social weight.

${ }^{12}$ See Section 5. Canzoneri et al. (1996) and Artis and Ehrman (2000) find nominal shocks to be the main determinant of exchange rate variability, whearas Clarida and Gali (1994) and Thomas (1997) find real shocks, especially demand shocks, to be important as well. Most studies agree that nominal (exchange rate) shocks are unimportant for relative output variability among countries, which is instead explained by real shocks, with supply shocks being the most important. Our assumptions are a compromise between the differing empirical results on relative output and exchange rate variability (see Section 8). Note that we have normalised nominal shocks to zero in the case of EMU membership. We have thus assumed away the possibilities of both monetary control errors by the ECB and exchange rate shocks vis-à-vis third countries. The real-world counterpart to exchange rate shocks in our model is thus the "net difference in nominal shocks" between non-membership and membership. 


\begin{tabular}{|c|c|c|c|c|c|c|c|c|c|}
\hline & \multicolumn{3}{|c|}{ Inside the EMU } & \multicolumn{5}{c|}{ Outside the EMU $^{a}$} \\
\hline & $\gamma=1$ & $\gamma=2$ & $\gamma=3$ & \multicolumn{3}{|c|}{$\gamma=1$} & \multicolumn{2}{c|}{$\gamma=2$} \\
\hline Variances & $\lambda=1,2,3$ & $\lambda=1,2,3$ & $\lambda=1,2,3$ & $\lambda=1$ & $\lambda=2$ & $\lambda=3$ & $\lambda=1$ & $\lambda=2,3$ & $\lambda=1,2,3$ \\
\hline$\sigma_{1}=\sigma_{2}=1$ & 0.90 & 0.91 & 0.93 & 0.54 & $1^{b}$ & $1^{b}$ & $1^{b}$ & $1^{b}$ & $1^{b}$ \\
\hline$\sigma_{1}=\sigma_{2}=1 / 2$ & 0.85 & 0.88 & 0.89 & 0.37 & $1^{b}$ & $1^{b}$ & $0.53^{c}$ & $1^{b}$ & $1^{b}$ \\
\hline$\sigma_{1}=2, \sigma_{2}=1$ & 0.99 & 0.99 & 0.99 & 0.25 & 0.19 & $1^{b}$ & 0.42 & $1^{b}$ & $1^{b}$ \\
\hline$\sigma_{1}=1, \sigma_{2}=2$ & 0.90 & 091 & 0.93 & $1^{b}$ & $1^{b}$ & $1^{b}$ & $1^{b}$ & $1^{b}$ & $1^{b}$ \\
\hline a) Unless stated otherwise there are three equilibria: $0<\mathrm{b}<1, \mathrm{~b}=1$ and $\mathrm{b}>1$. The table gives the \\
stable equilibrium with the lowest indexation. \\
b) This is the only equilibrium. It is stable. \\
c) There are three equilibria: two with $0<\mathrm{b}<1$ and one with $\mathrm{b}=1$. \\
\hline
\end{tabular}

Table 2: Equilibrium indexation when $\beta=0.5$

Inside the EMU, indexation is always partial. When $\beta=1$, indexation is around 0.5 , but in our main case with $\beta=0.5$ it is always close to unity. Outside the EMU, there are sometimes multiple equilibria and sometimes only one full-indexation equilibrium. The $b=1$ equilibria are more common when $(i)$ exchange rate shocks are large (as full indexation is the optimal response to such shocks); (ii) the central bank's weight on inflation, $\lambda$, is high (because exchange rate shocks are relatively more important when the central bank stabilises the CPI to a large extent in the case of demand and supply shocks), and (iii) the wage setters' weight on the real consumption wage, $\gamma$, is high (as stabilisation of the real consumption wage requires full indexation).

When there is partial indexation outside the EMU, larger exchange rate shocks push indexation closer to unity. Increases in both supply and demand variability (compare rows 2 and 3 with row 1) reduce indexation outside the EMU if it is partial. The result for supply variability is standard, whereas the result for demand variability is not. But the explanation is similar. Take the cases of negative supply or demand shocks. With a constant nominal wage, the CPI rises and employment falls in both cases (see Section 2.3). So, to the extent that a wage setter wants to stabilise employment, there is an incentive to reduce the nominal wage. This requires negative indexation. Larger supply and demand shocks enhance this incentive.

Whether or not indexation is higher inside the EMU than outside depends on the equilibrium outside. With partial indexation outside, indexation is usually higher inside than outside the EMU. The explanation is that both demand and supply variability give a motive for negative indexation outside the EMU, as discussed above. But with full indexation outside the EMU, indexation is lower inside in our examples. 


\section{Indexation in the presence of fixed costs}

So far, we have assumed indexation always to occur. A more realistic assumption is that indexation takes place only when the gains exceed some threshold. Following Gray (1978), Ball (1988), and Ball and Cechetti (1991), we shall assume a fixed cost of indexation, which depends on the existence of such arrangements per se, but is unrelated to the amount of indexation.

This cost can be thought of as being associated with the complexity of an indexation scheme as compared to an ordinary nominal wage contract. The cost may arise because of the psychological effort of computing optimal indexation formulas (as the authors of this article can verify), the effort of learning about the values of the parameters in such formulas, the difficulties of agreeing among employees on the degree of indexation, and the difficulties of negotiating the indexation arrangements with employers. Also, indexation arrangements usually increase the frequency of wage adjustments, so there are likely to be larger menu costs of wage changes (Ball and Cechetti, 1991).

Another possibility has to do not with indexation per se, but with the general cost of changing wage contracting arrangements, which tend to show a high degree of inertia (Traxler et al., 2001). If there have been no indexation arrangements, there may be a large cost of introducing them, because this requires a consensus on the need to change the design of contracts. This may be particularly difficult to achieve in those countries that, after a drawn-out process in the 1980s, dismantled such arrangements in response to earlier supply shocks.

When deciding whether or not to index, each wage setter compares the stabilisation gain with the cost. The anticipated gain depends on the expectation of what other wage setters will do: as indexation elsewhere increases price variability, each wage setter's gain from indexation is increasing in aggregate indexation (indexation arrangements are strategic complements). We analyse this in a way that is similar to the Ball and Romer (1991) model of how menu costs and coordination failures may interact to produce nominal wage rigidity in non-indexed contracts. ${ }^{13}$

We first compute the expected losses for an individual wage setter of not indexing and indexing, respectively, under the assumption that aggregate indexation is zero. The difference between these losses is the wage setter's stabilisation gain from indexation when others do not index, $\Delta E L_{0}$. We then compute the expected losses for an individual wage setter of not indexing and indexing, respectively, under the assumption that aggregate

\footnotetext{
${ }^{13}$ Ball and Romer (1991) did not analyse indexation formally, but noted the analogy to the problem they discussed.
} 
indexation is at the equilibrium level. The difference between theses losses is the stabilisation gain from indexation when others index, $\Delta E L_{b}$. The calculations are described in Appendix B.

We assume a uniform indexation cost, $F$. If $\Delta E L_{0}>F$, it always pays for each wage setter to index. The economy then ends up in an indexation equilibrium. If instead $\Delta E L_{b}<F$, it never pays for an individual wage setter to index. Then the economy ends up with zero indexation. If $\Delta E L_{0}<F<\Delta E L_{b}$, two equilibria are possible. If each wage setter expects others not to index, it is optimal not to index oneself, and the equilibrium implies zero indexation. If each wage setter expects all others to index, it is optimal to index oneself, and the outcome is an indexation equilibrium.

Table 3 gives $\Delta E L_{0}$ and $\Delta E L_{b}$ inside and outside the EMU, respectively, when $\beta=0.5$ and $\gamma=1$. When there are three equilibria outside the EMU, we show the same case as in Table 2. The losses are normalised by setting $\sigma_{v}^{2}=\sigma_{\theta}^{2}=\sigma_{\xi}^{2}=1$ in row 1 . In all cases shown, the expected gains from indexation are larger inside the EMU than outside. This can be shown to hold also for all the other cases in Tables 1 and $2{ }^{14}$

\begin{tabular}{|l|c|c|c|c|}
\hline & Outside & Inside & Outside & Inside \\
\hline Variances & Others do not index & Others index \\
\hline \multicolumn{5}{|c|}{$\lambda=1$} \\
\hline$\sigma_{1}=\sigma_{2}=1$ & 0.10 & 1.23 & 2.04 & 31.82 \\
\hline$\sigma_{1}=\sigma_{2}=1 / 2$ & 0.06 & 1.84 & 1.03 & 47.40 \\
\hline$\sigma_{1}=2, \sigma_{2}=1$ & 0.03 & 1.95 & 0.50 & 50.44 \\
\hline$\sigma_{1}=1, \sigma_{2}=2$ & 0.41 & 1.23 & 24.22 & 31.82 \\
\hline \multicolumn{5}{|c|}{$\lambda=2$} \\
\hline$\sigma_{1}=\sigma_{2}=1$ & 0.08 & 1.23 & 12.11 & 31.82 \\
\hline$\sigma_{1}=\sigma_{2}=1 / 2$ & 0.04 & 1.84 & 12.11 & 47.40 \\
\hline$\sigma_{1}=2, \sigma_{2}=1$ & 0.01 & 1.95 & 0.19 & 50.44 \\
\hline$\sigma_{1}=1, \sigma_{2}=2$ & 0.41 & 1.23 & 24.22 & 31.82 \\
\hline \multicolumn{5}{|c|}{$\lambda=3$} \\
\hline$\sigma_{1}=\sigma_{2}=1$ & 0.08 & 1.23 & 12.11 & 31.82 \\
\hline$\sigma_{1}=\sigma_{2}=1 / 2$ & 0.04 & 1.84 & 12.11 & 47.40 \\
\hline$\sigma_{1}=2, \sigma_{2}=1$ & 0.01 & 1.95 & 12.11 & 50.44 \\
\hline$\sigma_{1}=1, \sigma_{2}=2$ & 0.44 & 1.23 & 24.22 & 31.82 \\
\hline
\end{tabular}

Table 3: The expected gain of indexation for an individual wage setter

It is intuitive that the gains from indexation are larger inside than outside the EMU when equilibrium indexation in the absence of fixed costs is higher. It is less obvious

\footnotetext{
${ }^{14}$ The conclusion holds also if we look at the other equilibria outside the EMU than the partialindexation equilibria when there are multiple equilibria.
} 
why the gains are larger when equilibrium indexation inside is partial but full outside. However, the explanation is this. In the EMU, each wage setter chooses indexation to minimise employment and real wage variability arising from both demand and supply shocks. Hence, the gain of indexation is "large". Outside the EMU, (the full) indexation only protects against the employment and real wage instability caused by exchange rate shocks. Because the central bank then does not allow demand and supply shocks to affect the CPI, there is no need to stabilise the real wage through indexation against these shocks, and there is no point in trying to stabilise employment this way. Therefore, indexation outside the EMU gives only a "small" stabilisation gain.

The incentives to index are thus stronger inside than outside the EMU. This raises the possibility of a non-indexation equilibrium outside the EMU, but an indexation equilibrium inside. An economy joining the EMU might therefore move from non-indexation to indexation. This presupposes that the indexation cost is high enough to prevent indexation outside the EMU, but not high enough to prevent the larger gains from indexation inside the EMU to tilt the balance.

To reverse the result that indexation incentives are stronger inside than outside the EMU, exchange rate shocks must be much larger than in our examples. We experimented with increasing the size of these shocks to the values where the expected social welfare is the same inside and outside the EMU when wages are rigid, so that there would be no potential stabilisation cost of EMU membership (see Section 5.1). At these cut-off points, the stabilisation gains for each wage setter of indexing are still larger inside than outside the EMU when others are expected not to index, whereas the reverse holds when others are expected to do so. As the former case is the most relevant one when analysing a possible move from non-indexation to indexation, this sensitivity analysis seems rather to support our conclusions.

\section{Social welfare}

Table 4 reports how macroeconomic variability differs among various cases depending on whether indexation is chosen or not. We evaluate the social losses by aggregating the loss functions of wage setters. Columns 1 and 2 give the losses with zero indexation, and columns 3 and 4 the losses (gross of indexation costs) with indexation. We show the cases with $\beta=0.5, \lambda=1$ and $\gamma=1$, which are representative also for the other cases in Tables 
$1-2 .{ }^{15}$

\begin{tabular}{|c|c|c|c|c|}
\hline \multicolumn{5}{|c|}{ The social loss } \\
\hline & Non-indexation & \multicolumn{2}{c|}{ Indexation } \\
\hline Variances & Inside & Outside & Inside & Outside \\
\hline$\sigma_{1}=\sigma_{2}=1$ & 3.21 & 1.27 & 4.17 & 1.37 \\
\hline$\sigma_{1}=\sigma_{2}=1 / 2$ & 4.91 & 1.45 & 6.53 & 1.50 \\
\hline$\sigma_{1}=2, \sigma_{2}=1$ & 4.71 & 1.67 & 5.98 & 1.70 \\
\hline$\sigma_{1}=1, \sigma_{2}=2$ & 3.21 & 1.98 & 4.17 & 3.00 \\
\hline \multicolumn{5}{|c|}{ Employment variability } \\
\hline$\sigma_{1}=\sigma_{2}=1$ & 1.73 & 0.46 & 0.92 & 0.66 \\
\hline$\sigma_{1}=\sigma_{2}=1 / 2$ & 2.08 & 0.50 & 0.97 & 0.65 \\
\hline$\sigma_{1}=2, \sigma_{2}=1$ & 3.11 & 0.54 & 1.70 & 0.65 \\
\hline$\sigma_{1}=1, \sigma_{2}=2$ & 1.73 & 0.81 & 0.92 & 1.00 \\
\hline \multicolumn{5}{|c|}{ CPI variability } \\
\hline$\sigma_{1}=\sigma_{2}=1$ & 0.74 & 0.40 & 3.22 & 0.58 \\
\hline$\sigma_{1}=\sigma_{2}=1 / 2$ & 1.42 & 0.47 & 5.43 & 0.61 \\
\hline$\sigma_{1}=2, \sigma_{2}=1$ & 0.80 & 0.56 & 4.29 & 0.67 \\
\hline$\sigma_{1}=1, \sigma_{2}=2$ & 0.74 & 0.58 & 3.22 & 2.00 \\
\hline \multicolumn{5}{|c|}{ Real wage variability } \\
\hline$\sigma_{1}=\sigma_{2}=1$ & 0.74 & 0.40 & 0.03 & 0.12 \\
\hline$\sigma_{1}=\sigma_{2}=1 / 2$ & 1.42 & 0.47 & 0.12 & 0.24 \\
\hline$\sigma_{1}=2, \sigma_{2}=1$ & 0.80 & 0.56 & 0.0009 & 0.38 \\
\hline$\sigma_{1}=1, \sigma_{2}=2$ & 0.74 & 0.58 & 0.03 & 0 \\
\hline
\end{tabular}

Table 4: The social loss and macroeconomic variability $(\beta=0.5, \lambda=1$, and $\gamma=1)$

Columns 1 and 2, show that the social loss is larger inside the EMU than outside when wages are rigid. This reflects greater variability in all the three goal variables, although the difference is particularly large for employment. This difference in social welfare is the standard stabilisation cost of joining a monetary union. ${ }^{16}$

If wages are indexed inside the EMU but not indexed outside, the proper welfare comparison between membership and non-membership involves columns 2 and 3 . The table shows that indexation inside the EMU increases the difference in social welfare (also when neglecting indexation costs). This is so because the social loss in the EMU is always larger with indexation than without. Indexation in the EMU reduces both employment

\footnotetext{
${ }^{15}$ The computation formulas are reported in Calmfors and Johansson (2002). The calculations assume $\phi=\ln a$. Letting $\phi \neq \ln a$ would add a constant to all expected values, but not affect the comparisons.

${ }^{16}$ Social welfare is defined in the narrow sense of the welfare associated with macroeconomic variability. We do not take into account the efficiency gains from a common currency, which might outweigh the stabilisation costs (see e.g. Calmfors et al., 1997). For there to be a welfare gain of EMU membership in our model in the non-indexation case, exchange rate variability must be quite large. The cut-off values for $\sigma_{2}$ are 3.75 for $\sigma_{1}=1,5.91$ for $\sigma_{1}=1 / 2$, and 5.33 for $\sigma_{1}=2$.
} 


\begin{tabular}{|l|c|c|c|c|}
\hline & \multicolumn{2}{|c|}{ Inside } & \multicolumn{2}{c|}{ Outside } \\
\hline Variances & $\mathrm{SO}$ & $\mathrm{EI}$ & $\mathrm{SO}$ & $\mathrm{EI}$ \\
\hline$\sigma_{1}=\sigma_{2}=1$ & 0.41 & 0.90 & 0.15 & 0.54 \\
\hline$\sigma_{1}=\sigma_{2}=1 / 2$ & 0.35 & 0.85 & 0.07 & 0.37 \\
\hline$\sigma_{1}=2, \sigma_{2}=1$ & 0.52 & 0.99 & -0.005 & 0.25 \\
\hline$\sigma_{1}=1, \sigma_{2}=2$ & 0.41 & 0.90 & 0.31 & 1 \\
\hline SO socially optimal indexation, EI = equilibrium indexation. \\
The equilibrium levels of indexation are taken from Table 1. \\
\hline
\end{tabular}

Table 5: Socially optimal and equilibrium indexation levels $(\beta=0.5, \lambda=1$, and $\gamma=1)$

and real wage variability, but it increases price variability even more. If indexation in the EMU is to reduce the social loss, one has to assume either $\lambda: \mathrm{s}$ (the weight on inflation) that are considerably below unity ( 0.60 for equal supply and demand variability, 0.61 for large supply variability and 0.64 for large demand variability, if $\gamma=1$ ) or $\gamma:$ s (the weight on real wages) that are considerably above unity (2.59 for equal supply and demand variability, 2.56 for large supply variability, and 2.64 for large demand variability, if $\lambda=1$ ). But in these cases, too, welfare is lower inside than outside the EMU, so a move from nonindexation to indexation is at best an imperfect substitute for a national monetary policy. EMU membership always increases employment variability to a large extent.

Equilibrium indexation in the EMU leads to lower social welfare than nominal wage rigidity, because decentralised wage setters choose more indexation than is socially efficient: they do not take into account that indexation increases price variability. Table 5 shows that socially optimal indexation levels are much lower than the equilibrium levels (see Appendix C for the formulas).

Table 6 compares the social losses (gross of indexation costs) under socially optimal indexation and non-indexation. The table shows that a move to indexation in the EMU is an imperfect substitute for a national monetary policy in this case, too: the social loss under socially optimal indexation in the EMU is larger than the loss without indexation outside the EMU. The welfare differences between socially optimal indexation and non-indexation are small inside the EMU compared to the welfare differences between indexation and non-indexation for individual wage setters acting in a decentralised way (see Table 3). So, it is much less probable that EMU membership will entail a move from non-indexation to indexation if decisions are centralised rather than decentralised. The even smaller differences in welfare between socially optimal indexation and non-indexation outside the EMU explain why centralised decisions are likely to rule out indexation in this case. 


\begin{tabular}{|l|c|c|c|c|c|c|}
\hline Variances & \multicolumn{3}{|c|}{ Inside } & \multicolumn{3}{c|}{ Outside } \\
\hline & NI & SO & NI - SO & NI & SO & NI - SO \\
\hline$\sigma_{1}=\sigma_{2}=1$ & 3.21 & 3.02 & 0.19 & 1.273 & 1.265 & $7.7 \times 10^{-3}$ \\
\hline$\sigma_{1}=\sigma_{2}=1 / 2$ & 4.91 & 4.69 & 0.22 & 1.448 & 1.446 & $2.0 \times 10^{-3}$ \\
\hline$\sigma_{1}=2, \sigma_{2}=1$ & 4.71 & 4.34 & 0.37 & 1.666 & 1.666 & $2.0 \times 10^{-5}$ \\
\hline$\sigma_{1}=1, \sigma_{2}=2$ & 3.21 & 3.02 & 0.19 & 2.00 & 1.92 & 0.08 \\
\hline NI = non indexation, SO = socially optimal indexation \\
\hline
\end{tabular}

Table 6: The social loss with socially optimal indexation and non-indexation $(\beta=0.5$, $\lambda=1$, and $\gamma=1)$

\section{EMU membership and contract length}

Do the results on indexation carry over to other ways of modelling nominal wage flexibility? An alternative is to discard the possibility of indexation and let contracts determine only a nominal wage, but instead endogenise contract length. The assumption is then that uncertainty is increasing over time, so that optimal contract length reflects a tradeoff between contract costs on one hand and employment and real wage variability on the other.

Our model can easily be adapted in this way. We change to a continuous-time formulation and assume shocks to follow Wiener processes, which are the continous-time analogues of random walks. The expected values of the shocks are zero, but the variances increase over time. For example, the conditional forecast variance evaluated at time $T$ of the supply shock at the future time $t$ is $\operatorname{Var}_{T}\left(\theta_{t}\right)=(t-T) \sigma_{\theta}^{2}$, where $\sigma_{\theta}^{2}$ is now the instantaneous variance.

Outside the EMU, the national central bank is assumed to set it policy instrument so as to minimise the expectation of the loss function (8) at each point of time. This assumption captures that monetary policy is adjusted much more frequently than wages. The outcome is a policy response function like (11), but which now applies at each instant.

Wage setters have the same preferences over employment, the real consumption wage and the CPI as in Section 2, but they now incur a cost $\bar{C}$ each time a new contract is concluded. The total loss for a wage setter over a contract period is the sum of the contract cost and the squared deviations from the employment, real wage and CPI goals. Each wage setter's objective is now to choose contract length to minimise the total expected loss over a relevant time horizon. If we set the discount rate to zero and again take the CPI level as exogenous for each wage setter, this is equivalent to minimising the expected loss per unit of time: 


$$
E_{0}\left(L^{T U}\right)=\frac{1}{x_{i}}\left(\int_{0}^{x_{i}} E_{0}\left[l_{i}(t)^{2}\right] d t+\gamma \int_{0}^{x_{i}} E_{0}\left[\left(w_{i}(t)-p_{c}(t)-\phi\right)^{2}\right] d t+\bar{C}\right)
$$

\subsection{Contract length}

Choosing $x_{i}$ to minimize (14) subject to (11) and the continous-time versions of (2), (3), (6), (9) and (10) with $b=0$, we obtain:

$$
\begin{aligned}
& \frac{\partial E_{0}\left(L^{T U}\right)}{\partial x_{i}}=-\frac{1}{x_{i}^{2}}\left(\int_{0}^{x_{i}} E_{0}\left[l_{i}(t)^{2}\right] d t+\gamma \int_{0}^{x_{i}} E_{0}\left[\left(w_{i}(t)-p_{c}(t)-\phi\right)^{2}\right] d t+\bar{C}\right)+\frac{1}{x_{i}} E_{0}\left[l_{i}\left(x_{i}\right)^{2}\right] \\
& +\frac{1}{x_{i}} \gamma E_{0}\left[\left(w_{i}\left(x_{i}\right)-p_{c}\left(x_{i}\right)-\phi\right)^{2}\right]=0 .
\end{aligned}
$$

Contract length is chosen so that the cost savings per unit of time of lengthening the contract period balances the loss from larger employment and real wage fluctuations at the margin. Assuming symmetry and synchronisation of contract periods, contract length outside the EMU, $x^{O}$, can be solved out as (see Appendix D)

$$
x^{O}=\sqrt{\frac{2 \bar{C}(a+\beta(1-a))^{2}}{S \sigma_{\theta}^{2}+U \sigma_{v}^{2}+V \sigma_{\xi}^{2}}},
$$

where $S=\left(H_{0} \beta-(1-\beta)\right)^{2}+\gamma\left(\alpha-(a(1-\alpha)+\beta(1-a)) H_{0}\right)^{2}, U=\left(1+K_{0} \beta\right)^{2}+$ $\gamma\left(\alpha(1-a)+(a(1-\alpha)+\beta(1-a)) K_{0}\right)^{2}$, and $V=\beta^{2}+\gamma(a(1-\alpha)+\beta(1-a))^{2}$. Contract length is increasing in the contract cost and decreasing in the (instantaneous) variances of the shocks.

Proceeding as above, we can derive contract length inside the EMU as:

$$
x^{I}=\sqrt{\frac{2 \bar{C}(a+\beta(1-a))^{2}}{\left((1-\beta)^{2}+\gamma \alpha^{2}\right) \sigma_{\theta}^{2}+\left(1+\gamma \alpha^{2}(1-a)^{2}\right) \sigma_{v}^{2}}} .
$$

Again contract length is increasing in the contract cost. It is decreasing in the (instantanous) variances of both supply and demand shocks.

The ratio between the contract length outside and inside the EMU can be written:

$$
\frac{x^{O}}{x^{I}}=\sqrt{\frac{\left((1-\beta)^{2}+\gamma \alpha^{2}\right)+\left(1+\gamma \alpha^{2}(1-a)^{2}\right) \sigma_{1}}{S+U \sigma_{1}+V \sigma_{2}}} .
$$

In general, it is not clear whether this ratio is larger or smaller than unity. We resort again to numerical examples. Table 7 shows that wage contracts are shorter inside than outside the EMU in all our cases. 


\begin{tabular}{|l|l|l|l|}
\hline Variances & $\lambda=1$ & $\lambda=2$ & $\lambda=3$ \\
\hline$\sigma_{1}=\sigma_{2}=1$ & 2.85 & 2.71 & 2.53 \\
\hline$\sigma_{1}=\sigma_{2}=1 / 2$ & 3.59 & 3.39 & 3.13 \\
\hline$\sigma_{1}=2, \sigma_{2}=1$ & 3.54 & 3.32 & 3.04 \\
\hline$\sigma_{1}=1, \sigma_{2}=2$ & 1.77 & 1.72 & 1.64 \\
\hline
\end{tabular}

Table 7: The ratio between contract length outside and inside the $\operatorname{EMU}(\beta=0.5$, and $\gamma=1)$

\subsection{Social welfare}

As before, we also examine the social welfare consequences of increased nominal wage flexibility in the case of EMU membership. We do this for a time period that coincides with the contract length chosen outside the EMU. First, we compute the macroeconomic variability and the social loss (gross of contract costs) outside and inside the EMU, respectively, under the assumption that the contract length outside the EMU is also chosen inside, so that there is no endogenous adjustment of contract length. Second, we evaluate macroeconomic variability in the EMU under the assumption that wage setters then choose their desired contract length.

In Table 8, the first two columns give the macroeconomic outcomes inside the EMU when there is no adjustment of contract length. The third and fourth columns give the outcomes inside the EMU when there is such an adjustment. The measurement unit for the outcome variables is the contract cost, which we have normalised to unity. The computations formulas are given in Appendix D.

Employment, real consumption wage and price variability, and hence the social loss, are always larger inside than outside the EMU in the table. An adjustment of contract length in the EMU always reduces employment and real wage variability, but increases price variability. As in the indexation case, the increase in nominal wage flexibility in the EMU reduces social welfare with the $\lambda$ :s and $\gamma:$ s shown in the table, because the negative effects on price variability dominate the positive effects on employment and real wage variability. As before, this result is reversed for low $\lambda:$ s or high $\gamma:$ s. The cut-off values for $\lambda$ below which the adjustment of contract length leads to a reduction in the (gross) social loss are 0.68 (equal variances for supply and demand shocks), 0.64 (large supply shocks), and 0.71 (large demand shocks). The cut-off values for $\gamma$ are 2.70 (equal variances for supply and demand shocks), 2.63 (large supply shocks), and 2.81 (large demand shocks). 


\begin{tabular}{|c|c|c|c|c|c|c|}
\hline Variances & Inside, NA & \multicolumn{2}{|c|}{ Inside A } & \multicolumn{2}{c|}{ Outside } \\
\hline & $\lambda=1$ & $\lambda=2$ & $\lambda=1$ & $\lambda=2$ & $\lambda=1$ & $\lambda=2$ \\
\hline \multicolumn{7}{|c|}{ Employment variability } \\
\hline$\sigma_{1}=\sigma_{2}=1$ & 1.99 & 1.90 & 1.05 & 1.01 & 0.53 & 0.67 \\
\hline$\sigma_{1}=\sigma_{2}=1 / 2$ & 4.27 & 4.03 & 2.18 & 2.07 & 1.03 & 1.33 \\
\hline$\sigma_{1}=2, \sigma_{2}=1$ & 2.82 & 2.65 & 1.44 & 1.36 & 0.49 & 0.67 \\
\hline$\sigma_{1}=1, \sigma_{2}=2$ & 1.24 & 1.20 & 0.79 & 0.78 & 0.58 & 0.66 \\
\hline \multicolumn{7}{|c|}{ CPI variability } \\
\hline$\sigma_{1}=\sigma_{2}=1$ & 0.85 & 0.81 & 2.57 & 2.42 & 0.47 & 0.33 \\
\hline$\sigma_{1}=\sigma_{2}=1 / 2$ & 2.91 & 2.75 & 7.66 & 7.22 & 0.97 & 0.67 \\
\hline$\sigma_{1}=2, \sigma_{2}=1$ & 0.72 & 0.68 & 2.79 & 2.61 & 0.51 & 0.33 \\
\hline$\sigma_{1}=1, \sigma_{2}=2$ & 0.53 & 0.51 & 1.36 & 1.29 & 0.42 & 0.33 \\
\hline \multicolumn{7}{|c|}{ Real consumption variability } \\
\hline$\sigma_{1}=\sigma_{2}=1$ & 0.85 & 0.81 & 0.64 & 0.61 & 0.47 & 0.33 \\
\hline$\sigma_{1}=\sigma_{2}=1 / 2$ & 2.91 & 2.75 & 1.93 & 1.83 & 0.97 & 0.67 \\
\hline$\sigma_{1}=2, \sigma_{2}=1$ & 0.72 & 0.68 & 0.63 & 0.59 & 0.51 & 0.33 \\
\hline$\sigma_{1}=1, \sigma_{2}=2$ & 0.53 & 0.51 & 0.43 & 0.42 & 0.42 & 0.34 \\
\hline \multicolumn{7}{|c|}{ The social loss } \\
\hline$\sigma_{1}=\sigma_{2}=1$ & 3.70 & 4.34 & 4.23 & 6.46 & 1.47 & 1.67 \\
\hline$\sigma_{1}=\sigma_{2}=1 / 2$ & 10.10 & 12.20 & 11.78 & 17.36 & 2.97 & 2.13 \\
\hline$\sigma_{1}=2, \sigma_{2}=1$ & 4.27 & 4.68 & 4.86 & 7.17 & 1.51 & 1.67 \\
\hline$\sigma_{1}=1, \sigma_{2}=2$ & 2.31 & 2.75 & 2.57 & 3.77 & 1.42 & 1.67 \\
\hline $\mathrm{NA}=$ non-adjustment of contract length, A = adjustment of contract length \\
\hline
\end{tabular}

Table 8: Macroeconomic variability and social loss $(\beta=0.5$, and $\gamma=1)$

\section{Discussion}

It is a commonly believed that membership in a monetary union like the EMU tends to increase macroeconomic variability. We show that if this is the case, then nominal wage flexibility is likely to increase with monetary union membership. It could lead to a move from non-indexation to indexation. Similarly, contract length may be shortened.

More flexible nominal wages reduce the variability of employment and the real consumption wage, but at a cost of more price variability. Hence, increased nominal wage flexibility in a monetary union might reduce social welfare. If this is not to occur, the relative weight of inflation versus employment in the social welfare function must be below unity (0.6-0.7) or the relative weight of the real consumption wage considerably above unity (2.5-2.8). But also then, increased nominal wage flexibility in a monetary union is a very imperfect substitute for a national monetary policy, mainly because it offsets the tendency to increased employment variability only partially. In all our examples, the socially optimal degree of indexation is much lower than equilibrium indexation. Hence, 
wage indexation is more likely if indexation decisions are taken in a decentralised than in a centralised fashion.

As to possible extensions, an obvious drawback of our model concerns the transmission mechanism of monetary policy. We have focused exclusively on the exchange rate channel of monetary policy in the Krugman-Obstfeld textbook tradition (Krugman and Obstfeld, 2000) and neglected the interest rate channel. To elaborate also the latter channel is a natural next step.

We have assumed the same weight on inflation in the preference functions of the central bank and society. An alternative would be to assume more inflation aversion in the central bank's preference function than in the social welfare function. Some experimenting suggests, however, that such modifications would not change the results substantially. But a deeper analysis requires that the welfare functions are derived from well-specified preferences of the individual agents.

An extended analysis should analyse the interaction between different economies. This would require an explicit modelling of both symmetric and asymmetric shocks. Such an analysis would be more complex and is likely to result in multiple indexation equilibria not only outside the monetary union, but also inside.

Our analysis shares the feature with the earlier literature that indexation is not subject to downward nominal rigidity: indexation is symmetric and could lead to both higher and lower wage increases than in the base contract. An alternative is to allow for asymmetric indexation, i.e. index clauses that are triggered only when inflation is above a certain threshold. This is likely to result in contracts with a lower base wage and higher indexation than in our analysis, allowing wage setters to use the indexation clauses symmetrically to achieve both upward and downward flexibility in this case as well (see Cover and Van Hoose, 2002).

It might also be worthwhile to introduce pricing-to-market assumptions, according to which there is only a partial pass-through of exchange rate changes to import prices in local currency (see e.g. Lane, 2001; or Obstfeld, 2002). This would reconcile the empirical findings that exchange rate shocks are not very important for output and inflation varaibility, although they are the main determinant of exchange rate volatility according to several studies. 


\section{References}

Aizenman, J., (1985), "Wage Flexibility and Openess", Quarterly Journal of Economics, vol. 100 .

Aizenman, J. and Frenkel, J., (1985), "Optimal Wage Indexation, Foreign Exchange Intervention, and Monetary Policy", American Economic Review, vol. 76.

Artis, M. J. and Ehrmann, M., (2000), "The Exchange Rate - A Shock-Absorber or Source of Shocks? A Study of Four Open Economies", CEPR Discussion Paper 2550.

Akerlof, G. and Yellen, J., (1990), "The Fair Wage-Effort Hypothesis and Unemployment", Quarterly Journal of Economics, vol. 105.

Ball, L., (1987), "Externalities from Contract Length", American Economic Review, vol. 77 .

Ball, L., (1988), "Is Equilibrium Indexation Efficient?", Quarterly Journal of Economics, vol. 103.

Ball, L. and Romer, D., (1991), "Sticky Prices As Coordination Failure", American Economic Review, vol. 81.

Ball, L. and Cecchetti, S.G., (1991), "Wage Indexation and Discretionary Monetary Policy", American Economic Review, vol. 81.

Bentolila, S. and Saint-Paul, G., (2001), "Will EMU increase Eurosclerosis", forthcoming in C. Wyploz (ed.), EMU: Impact on Europe and the World, Oxford University Press.

Bewley, T., (1998), "Why Not Cut Pay?", European Economic Review, vol. 42.

Blanchard, O. and Kiyotaki, N., (1987), "Monopolistic Competition and the Effects of Aggregate Demand", American Economic Review, vol. 77.

Blanchard, O., (1979), "Wage Indexing Rules and the Behaviour of the Economy", Journal of Political Economy, vol. 87.

Broadbent, B. and Barro, R., (1997), "Central Bank Preferences and Macroeconomic Equilibrium", Journal of Monetary Economics, vol. 39.

Bryson, J.H., Chen, C., and Van Hoose, D.D., (1998), "Implications of Economic Interdependence for Endogenous Wage Indexation Decisions", Scandinavian Journal of Economics, vol. 100.

Canzoneri, M., Valles, J., and Vinals, J., (1996), ”Do Exchange Rates Move to Address International Macroeconomic Imbalances?", CEPR Discussion Paper No. 1498.

Calmfors, L., (2001), "Unemployment, Labor Market Reform, and Monetary Union", Journal of Labor Economics, vol. 19. 
Calmfors, L., Flam, H., Gottfries, N., Haaland Matlary, J., Jerneck, M., Lindahl, R., Nordh Berntsson, C., Rabinowicz, E. and Vredin, A., (1997), EMU - A Swedish Perspective: the Report of the Calmfors Commission, Dordrecht: Kluwer.

Calmfors, L. and Johansson, Å., (2002), "Nominal Wage Flexibility, Wage Indexation and Monetary Union", in Essays on Macroeconomic Fluctuations and Nominal Wage Rigidity, IIES Monograph Series, No. 43.

Clarida, R. and Gali, J., (1994), "Sources of Real Exchange Rate Fluctuations: How Important Are Nominal Shocks?", Carnegie-Rochester Conference Series on Public Policy, vol. 41.

Corricelli, F., Cukierman, A. and Dalmazzo, A., (2000), "Monetary Institutions, Moopolistic Competition, Unionized Labor Markets and Economic Performance", University of Sienna.

Cover, J.P. and Van Hoose, D.D., (2002), "Asymmetric Wage Indexation", Atlantic Economic Journal, vol 30.

Fischer, S., (1977), "Long-Term Contracts, Rational Expectations and the Optimal Money Supply Rule", Journal of Political Economy, vol. 85.

Flood, R.P. and Marion, N.P., (1982), "The Transmission of Disturbances Under Alternative Exchange-Rate Regimes with Optimal Indexation", Quarterly Journal of Economics, vol. 97.

Gottfries, N., (1992), "Insiders, Outsiders and Nominal Wage Contracts", Journal of Political Economy, vol. 100.

Gray, J.A., (1976), "Wage Indexation: A Macroeconomic Approach", Journal of Monetary Economics, vol. 2.

Gray, J.A., (1978), "On Indexation and Contract Length", Journal of Political Economy, vol. 86 .

Heinemann, F., (1999), "Flexibility of Wage Contracts and Monetary Policy", University of Munich.

Holden, S., (1997), "Wage Bargaining, Holdout and Inflation", Oxford Economic Papers, vol. 49 .

Hutchison, M.M. and Walsh, C.E, (1998), "The Output-Inflation Trade-Off and Central Bank Reform: Evidence from New Zealand", The Economic Journal, vol. 108.

Inkomstpolitisk avtal för åren 2001-02, (2000), Helsinki, 15 December.

Krugman, P. and Obstfeld, M., (2000), "International Economics: Theory and Policy", 5th edition, Addison-Wesley.

Lane, P. R, (2001), "The New Open Economy Macroeconomics: A Survey", Journal 
of International Economics, vol. 54.

Lane, P. R., (2000), "Asymmetric Shocks and Monetary Policy in a Currency Union", Scandinavian Journal of Economics, vol. 102.

Leichter, J., (1998), "Optimal Wage Indexation for a Monetary Union with Country Specific Shocks", Working Paper No. 400, Department of Economics, University of California, Santa Cruz.

Milesi-Ferretti, G.M., (1994), "Wage Indexation and Time Consistency", Journal of Money, Credit and Banking, vol. 26.

Obstfeld, M., (2001), "International Macroeconomics: Beyond the Mundell-Flemming Model", NBER Working Paper 8369.

OECD, (2001), Economic Survey of Spain, June 2001.

Rogoff, K., (1985), "The Optimal Degree of Commitment to an Intermediate Monetary Target", Quarterly Journal of Economics, vol. 100.

Sibert, A. and Sutherland, A., (2000), "Monetary Union and Labour Market Reform", Journal of International Economics, vol. 51.

Thomas, A., (1997), "Is the Exchange Rate a Shock Absorber? The Case of Sweden", IMF Working Paper 97/176.

Waller, J. and Van Hoose, D.D, (1992), "Discretionary Monetary Policy and Socially Efficient Wage Indexation", Quarterly Journal of Economics, vol. 107.

Walsh, C. E., (1995), "Central Bank Independence and the Short-Run Output-Inflation Trade-Off in the European Community" in B. Eichengreen, J. Frieden and J. von Hagen (eds), Monetary and Fiscal Policy in an Integrated Europe, New York and London: Springer.

Van Hoose, D.D., and Waller, J., (1991), "Discretion, Wage Indexation and Inflation", Southern Economic Journal, vol. 58.

\section{A Indexation without indexation costs}

\section{A.1 The central bank's decision rule}

In (11) we have $K=(-(1-b)(1-\alpha b) \beta-\lambda \alpha((1-\alpha) a+\beta(1-a))(1-a)) / V$ and $H=(\alpha \lambda((1-\alpha) a+\beta(1-a))+\beta(1-b)(1-\beta-\alpha b)) / V$, where $V=(1-b)^{2} \beta^{2}+$

$\lambda((1-\alpha) a+\beta(1-a))^{2} .0 \leq b \leq 1$ and $0<\beta \leq 1$ always imply that $K<0 . b=0$ and $0<\beta \leq 1$ always imply $H>0 . \quad 0 \leq b \leq 1$ and $0<\beta \leq 1$ imply $H>0$ for the parameter values we subsequently use. 


\section{A.2 Equilibrium indexation outside the EMU}

In (13) we have: $A=(a b D-\sqrt{D}((1-a)(1-\beta)-\beta(1-a) H) Z) / T, B=a b E / T+$ $(\sqrt{E}((1-a)+\beta(1-a) K) Z) / T, C=(a b F+\sqrt{F} \beta(1-a) Z) / T, T=a+\beta(1-a)$, $D=(((1-\alpha) a+\beta(1-a)) H-\alpha)^{2}, E=(((1-\alpha) a+\beta(1-a)) K+\alpha(1-a))^{2}, F=$ $((1-\alpha) a+\beta(1-a))^{2}$ and $Z=a+\beta(1-a)-a b \alpha$.

\section{A.3 The $b=1$ equilibrium}

Using equations (6), (7), (9), (10), (11) and $w_{i 0}=w_{0}=p_{c}^{e}+\phi+l^{e} /(\gamma(1-a))$, which follows from the FOC for $w_{i 0}$, we can derive that:

$$
\begin{aligned}
p_{c}= & \frac{(((1-\alpha) a+\beta(1-a)) H-\alpha)}{a+\beta(1-a)-a b \alpha} \theta+\frac{(((1-\alpha) a+\beta(1-a)) K+\alpha(1-a))}{a+\beta(1-a)-a b \alpha} v \\
& +\frac{(1-\alpha) a+\beta(1-a)}{a+\beta(1-a)-a b \alpha} \xi
\end{aligned}
$$

When $b=1, H=\alpha /((1-\alpha) a+\beta(1-a))$ and $K=-\alpha(1-a) /((1-\alpha) a+\beta(1-a))$. Substituting these expressions into (A1) gives $p_{c}=\xi$.

\section{B Indexation in the presence of fixed costs}

The expected loss for wage setter $i$ of not indexing when others are not expected to do so either, $E\left(L_{i}^{M}(0,0)\right)$, where $M=I, O$ denotes EMU membership and non-membership, respectively, is obtained by evaluating the expectation of (4) with $b_{i}=b=0$. To evaluate the loss of indexing when others are expected not to index, $E\left(L_{i}^{M}\left(b_{i}, 0\right)\right)$, we first compute the optimal degree of indexation in this case by minimising the expectation of (4) when $b=0$. It is:

$$
b_{i}=\frac{(1-a)(1-\beta)+\gamma \alpha(1-a)^{2}+(1-a)^{2} \sigma_{1}+\gamma \alpha(1-a)^{4} \sigma_{1}}{\alpha+\gamma \alpha(1-a)^{2}+\alpha(1-a)^{2} \sigma_{1}+\gamma \alpha(1-a)^{4} \sigma_{1}},
$$

inside the EMU. Outside the EMU it is obtained by setting $b=0$ in (13). The expected losses are obtained by setting $b_{i}$ equal to these values and $b=0$.

The expected loss for wage setter $i$ when he/she does not index, but others are expected to do so, $E\left(L_{i}^{M}(0, b)\right)$, is computed by setting $b_{i}=0$ and $b$ equal to the lowest value that is a solution to (13) when $b_{i}=b$ in the expectation of (4). The expected loss for wage setter $i$ when he/she indexes and also others are expected to do so, $E\left(L_{i}^{M}(b, b)\right)$, is obtained by setting $b_{i}=b$ equal to the lowest value that is a solution to (13). All expected losses are calculated under the assumption that $E\left(p_{c}^{2}\right)$ is exogenous. 
The stabilisation gains for wage setter $i$ of indexing are:

$$
\begin{aligned}
& \Delta E L_{0}=E\left(L_{i}^{M}(0,0)\right)-E\left(L_{i}^{M}\left(b_{i}, 0\right)\right) \\
& \Delta E L_{b}=E\left(L_{i}^{M}(0, b)\right)-E\left(L_{i}^{M}(b, b)\right) .
\end{aligned}
$$

The exact expressions are reported in Calmfors and Johansson (2002).

\section{Socially optimal indexation}

Minimising the expectation of (4) w.r.t $b$ subject to (2), (3), (6), (9), (10), and a fixed exchange rate gives the socially optimal indexation in the EMU as:

$$
b=\frac{\frac{1}{\alpha}\left(\beta(1-\beta)+\beta(1-a) \sigma_{1}\right)-\lambda a \alpha\left(1+(1-a)^{2} \sigma_{1}\right)+\gamma \sqrt{F}\left(1+(1-a)^{2} \sigma_{1}\right)}{\beta+\beta(1-a) \sigma_{1}+\gamma \sqrt{F}\left(1+(1-a)^{2} \sigma_{1}\right)} .
$$

Minimising the expectation of(4) w.r.t $b$ subject to (2), (3), (6), (7), (9), (10) and (11) gives the socially optimal indexation outside the EMU as:

$$
\begin{aligned}
b= & \frac{\widehat{A}+\widehat{B} \sigma_{1}+\widehat{C} \sigma_{2}-\lambda\left(J+Q \sigma_{1}+L \sigma_{2}\right)-\gamma(b-1) \sqrt{F}((b-1) \sqrt{D} Z d H / d b+D)}{\widehat{D}+\widehat{E} \sigma_{1}+\widehat{F} \sigma_{2}}- \\
& \frac{\gamma(b-1) \sqrt{F}((b-1) \sqrt{E} Z d K / d b+E)}{\widehat{D}+\widehat{E} \sigma_{1}+\widehat{F} \sigma_{2}} \sigma_{1},
\end{aligned}
$$

where $\widehat{A}=(1-\beta-\beta H)(\alpha \beta-\beta H \sqrt{F})+(1-\beta-\beta H)(\beta(1-b) Z d H / d b), \widehat{C}=\beta^{2} \sqrt{F}$, $\widehat{B}=(\beta K+1)(\alpha \beta(1-a)+\beta K \sqrt{F}-\beta(1-b) Z d K / d b), \widehat{D}=(\alpha-\beta H)(\alpha \beta-\beta H \sqrt{F})+$ $(\alpha-\beta H)(\beta(1-b) Z d H / d b), \widehat{E}=(\beta K+\alpha)(\beta K \sqrt{F}+\alpha \beta(1-a)-\beta(1-b) Z d K / d b)$, $\widehat{F}=\beta^{2}(a(1-\alpha)+\beta(1-a)), J=D a \alpha+\sqrt{D} \sqrt{F} Z d H / d b, Q=\sqrt{E} \sqrt{F} Z d K / d b+E a \alpha$, and $L=a \alpha F$.

\section{Contract length}

We assume that wage contracts are synchronised at time $t=0$, so that there is no staggering and we obtain a symmetric equilibrium. The FOC for the optimal wage during the contract period, which we denote $w_{i}(0)$, is then:

$$
\begin{aligned}
& \frac{\partial E_{0}\left(L^{T U}\right)}{\partial w_{i}(0)}=-\frac{2}{1-a} \int_{0}^{x} E_{0}\left(-\frac{1}{1-a}\left(w_{i}(0)-p(t)-\ln a-\theta(t)\right)\right) d t \\
& +2 \gamma \int_{0}^{x} E_{0}\left(\left(w_{i}(0)-p_{c}-\phi\right)\right) d t=0 .
\end{aligned}
$$


Using that $\theta(0)=v(0)=\xi(0)=0$, we can derive that:

$$
w(0)=w_{i}(0)=\frac{1}{\gamma(1-a)} l^{e}+p_{c}^{e}+\phi .
$$

Letting $\phi=\ln a$, expected employment variability outside the EMU can be derived as:

$$
E_{0}^{O}\left[l_{i}(t)^{2}\right]=\frac{\left(H_{0} \beta-(1-\beta)\right)^{2}}{(a+\beta(1-a))^{2}} t{\sigma^{2}}_{\theta}+\frac{\left(1+K_{0} \beta\right)^{2}}{(a+\beta(1-a))^{2}} t \sigma_{v}^{2}+\frac{\beta^{2}}{(a+\beta(1-a))^{2}} t \sigma_{\xi}^{2},
$$

where $H_{0}$ and $K_{0}$ are obtained from $H$ and $K$ in (11) by setting $b=0$. Expected CPI and real consumption wage variability outside the EMU is:

$$
E_{0}^{O}\left[p_{c}(t)\right]^{2}=E_{0}^{O}\left[\left(w_{i}(0)-p_{c}(t)-\phi\right)^{2}\right]=\frac{\bar{D} t \sigma_{\theta}^{2}+\bar{E} t \sigma_{v}^{2}+\bar{F} t \sigma_{\xi}^{2}}{(a+\beta(1-a))^{2}},
$$

where $\bar{D}, \bar{E}$ and $\bar{F}$ are obtained from Appendix A.2 by setting $b=0$.

The expected variabilities inside the EMU are:

$$
\begin{gathered}
E_{0}^{I}\left[l_{i}(t)^{2}\right]=\frac{(1-\beta)^{2} t \sigma_{\theta}^{2}+\sigma_{v}^{2} t}{(a+\beta(1-a))^{2}}, \\
E_{0}^{I}\left[p_{c}(t)^{2}\right]=E_{0}^{I}\left[\left(w_{i}(0)-p_{c}(t)-\phi\right)^{2}\right]=\frac{\alpha^{2} t \sigma_{\theta}^{2}+\alpha^{2}(1-a)^{2} t \sigma_{v}^{2}}{(a+\beta(1-a))^{2}} .
\end{gathered}
$$

The expected gross social losses from macroeconomic variability when actual contract length both outside and inside the EMU = the optimal contract length for a local wage setter outside the EMU, where $O$ and $I$ denote non-membership and membership, respectively are:

$$
\begin{aligned}
& \bar{E}_{0}^{O}\left(L^{T U}\right)=\int_{0}^{x^{O}} E_{0}\left[l(t)^{2}\right] d t+\int_{0}^{x^{o}} E_{0}\left[p_{c}(t)^{2}\right] d t+\int_{0}^{x^{o}} E_{0}\left[\left(w(0)-p_{c}(t)-\phi\right)^{2}\right] d t, \\
& \bar{E}_{0}^{I}\left(L^{T U}\right)=\int_{0}^{x^{O}} E_{0}\left[l(t)^{2}\right] d t+\int_{0}^{x^{o}} E_{0}\left[p_{c}(t)^{2}\right] d t+\int_{0}^{x^{o}} E_{0}\left[\left(w(0)-p_{c}(t)-\phi\right)^{2}\right] d t .
\end{aligned}
$$

The expected gross social loss inside the EMU over the period $x^{O}$ when wage setters choose their optimal contract length, $x^{I}$, inside the EMU is:

$$
\begin{aligned}
\widehat{E}_{0}^{I}\left(L^{T U}\right)= & \int_{0}^{x^{I}} E_{0}\left[l(t)^{2}\right] d t+\int_{x^{I}}^{x^{O}} E_{0}\left[l(t)^{2}\right] d t+\int_{0}^{x^{I}} E_{0}\left[p_{c}(t)^{2}\right] d t+\int_{x^{I}}^{x^{O}} E_{0}\left[p_{c}(t)^{2}\right] d t+ \\
& \int_{0}^{x^{I}} E_{0}\left[\left(w(0)-p_{c}(t)-\phi\right)^{2}\right] d t+\int_{x^{I}}^{x^{O}} E_{0}\left[\left(w(0)-p_{c}(t)-\phi\right)^{2}\right] d t .
\end{aligned}
$$


In Table 8, the social losses for each shock configuration and inflation weight are measured for a time period that equals the contract period outside the EMU in this case. Hence, social losses can be compared for a given shock configuration and a given inflation weight only, but not across shock configurations and inflation weights. Calmfors and Johansson (2002) report the computation formulas. 


\section{CESifo Working Paper Series}

692 Amihai Glazer, Vesa Kanniainen, and Mikko Mustonen, Innovation of Network Goods: A Non-Innovating Firm Will Gain, March 2002

693 Helmuth Cremer, Jean-Marie Lozachmeur, and Pierre Pestieau, Social Security, Retirement Age and Optimal Income Taxation, April 2002

694 Rafael Lalive and Josef Zweimüller, Benefit Entitlement and the Labor Market: Evidence from a Large-Scale Policy Change, April 2002

695 Hans Gersbach, Financial Intermediation and the Creation of Macroeconomic Risks, April 2002

696 James M. Malcomson, James W. Maw, and Barry McCormick, General Training by Firms, Apprentice Contracts, and Public Policy, April 2002

697 Simon Gächter and Arno Riedl, Moral Property Rights in Bargaining, April 2002

698 Kai A. Konrad, Investment in the Absence of Property Rights: The Role of Incumbency Advantages, April 2002

699 Campbell Leith and Jim Malley, Estimated General Equilibrium Models for the Evaluation of Monetary Policy in the US and Europe, April 2002

700 Yin-Wong Cheung and Jude Yuen, Effects of U.S. Inflation on Hong Kong and Singapore, April 2002

701 Henry Tulkens, On Cooperation in Musgravian Models of Externalities within a Federation, April 2002

702 Ralph Chami and Gregory D. Hess, For Better or For Worse? State-Level Marital Formation and Risk Sharing, April 2002

703 Fredrik Andersson and Kai A. Konrad, Human Capital Investment and Globalization in Extortionary States, April 2002

704 Antonis Adam and Thomas Moutos, The Political Economy of EU Enlargement: Or, Why Japan is not a Candidate Country?, April 2002

705 Daniel Gros and Carsten Hefeker, Common Monetary Policy with Asymmetric Shocks, April 2002

706 Dirk Kiesewetter and Rainer Niemann, Neutral and Equitable Taxation of Pensions as Capital Income, April 2002

707 Robert S. Chirinko, Corporate Taxation, Capital Formation, and the Substitution Elasticity between Labor and Capital, April 2002 
708 Frode Meland and Gaute Torsvik, Structural Adjustment and Endogenous Worker Recall Probabilities, April 2002

709 Rainer Niemann and Caren Sureth, Taxation under Uncertainty - Problems of Dynamic Programming and Contingent Claims Analysis in Real Option Theory, April 2002

710 Thomas Moutos and William Scarth, Technical Change and Unemployment: Policy Responses and Distributional Considerations, April 2002

711 Günther Rehme, (Re-)Distribution of Personal Incomes, Education and Economic Performance Across Countries, April 2002

712 Thorvaldur Gylfason and Gylfi Zoega, Inequality and Economic Growth: Do Natural Resources Matter?, April 2002

713 Wolfgang Leininger, Contests over Public Goods: Evolutionary Stability and the FreeRider Problem, April 2002

714 Ernst Fehr and Armin Falk, Psychological Foundations of Incentives, April 2002

715 Giorgio Brunello, Maria Laura Parisi, and Daniela Sonedda, Labor Taxes and Wages: Evidence from Italy, May 2002

716 Marta Aloi and Huw Dixon, Entry Dynamics, Capacity Utilisation and Productivity in a Dynamic Open Economy, May 2002

717 Paolo M. Panteghini, Asymmetric Taxation under Incremental and Sequential Investment, May 2002

718 Ben J. Heijdra, Christian Keuschnigg, and Wilhelm Kohler, Eastern Enlargement of the EU: Jobs, Investment and Welfare in Present Member Countries, May 2002

719 Tapio Palokangas, The Political Economy of Collective Bargaining, May 2002

720 Gilles Saint-Paul, Some Evolutionary Foundations for Price Level Rigidity, May 2002

721 Giorgio Brunello and Daniela Sonedda, Labor Tax Progressivity, Wage Determination, and the Relative Wage Effect, May 2002

722 Eric van Damme, The Dutch UMTS-Auction, May 2002

723 Paolo M. Panteghini, Endogenous Timing and the Taxation of Discrete Investment Choices, May 2002

724 Achim Wambach, Collusion in Beauty Contests, May 2002

725 Dominique Demougin and Claude Fluet, Preponderance of Evidence, May 2002

726 Gilles Saint-Paul, Growth Effects of Non Proprietary Innovation, May 2002 
727 Subir Bose, Gerhard O. Orosel, and Lise Vesterlund, Optimal Pricing and Endogenous Herding, May 2002

728 Erik Leertouwer and Jakob de Haan, How to Use Indicators for 'Corporatism' in Empirical Applications, May 2002

729 Matthias Wrede, Small States, Large Unitary States and Federations, May 2002

730 Christian Schultz, Transparency and Tacit Collusion in a Differentiated Market, May 2002

731 Volker Grossmann, Income Inequality, Voting Over the Size of Public Consumption, and Growth, May 2002

$732 \mathrm{Yu}-\mathrm{Fu}$ Chen and Michael Funke, Working Time and Employment under Uncertainty, May 2002

733 Kjell Erik Lommerud, Odd Rune Straume, and Lars Sørgard, Downstream Merger with Oligopolistic Input Suppliers, May 2002

734 Saku Aura, Does the Balance of Power Within a Family Matter? The Case of the Retirement Equity Act, May 2002

735 Sandro Brusco and Fausto Panunzi, Reallocation of Corporate Resources and Managerial Incentives in Internal Capital Markets, May 2002

736 Stefan Napel and Mika Widgrén, Strategic Power Revisited, May 2002

737 Martin W. Cripps, Godfrey Keller, and Sven Rady, Strategic Experimentation: The Case of Poisson Bandits, May 2002

738 Pierre André Chiappori and Bernard Salanié, Testing Contract Theory: A Survey of Some Recent Work, June 2002

739 Robert J. Gary-Bobo and Sophie Larribeau, A Structural Econometric Model of Price Discrimination in the Mortgage Lending Industry, June 2002

740 Laurent Linnemer, When Backward Integration by a Dominant Firm Improves Welfare, June 2002

741 Gebhard Kirchgässner and Friedrich Schneider, On the Political Economy of Environmental Policy, June 2002

742 Christian Keuschnigg and Soren Bo Nielsen, Start-ups, Venture Capitalits, and the Capital Gains Tax, June 2002

743 Robert Fenge, Silke Uebelmesser, and Martin Werding, Second-best Properties of Implicit Social Security Taxes: Theory and Evidence, June 2002

744 Wendell Fleming and Jerome Stein, Stochastic Optimal Control, International Finance and Debt, June 2002 
745 Gene M. Grossman, The Distribution of Talent and the Pattern and Consequences of International Trade, June 2002

746 Oleksiy Ivaschenko, Growth and Inequality: Evidence from Transitional Economies, June 2002

747 Burkhard Heer, Should Unemployment Benefits be Related to Previous Earnings?, July 2002

748 Bas van Aarle, Giovanni Di Bartolomeo, Jacob Engwerda, and Joseph Plasmans, Staying Together or Breaking Apart: Policy-makers' Endogenous Coalitions Formation in the European Economic and Monetary Union, July 2002

749 Hans Gersbach, Democratic Mechanisms: Double Majority Rules and Flexible Agenda Costs, July 2002

750 Bruno S. Frey and Stephan Meier, Pro-Social Behavior, Reciprocity or Both?, July 2002

751 Jonas Agell and Helge Bennmarker, Wage Policy and Endogenous Wage Rigidity: A Representative View From the Inside, July 2002

752 Edward Castronova, On Virtual Economies, July 2002

753 Rebecca M. Blank, U.S. Welfare Reform: What's Relevant for Europe?, July 2002

754 Ruslan Lukach and Joseph Plasmans, Measuring Knowledge Spillovers Using Patent Citations: Evidence from the Belgian Firm's Data, July 2002

755 Aaron Tornell and Frank Westermann, Boom-Bust Cycles in Middle Income Countries: Facts and Explanation, July 2002

756 Jan K. Brueckner, Internalization of Airport Congestion: A Network Analysis, July 2002

757 Lawrence M. Kahn, The Impact of Wage-Setting Institutions on the Incidence of Public Employment in the OECD: 1960-98, July 2002

758 Sijbren Cnossen, Tax Policy in the European Union, August 2002

759 Chandima Mendis, External Shocks and Banking Crises in Developing Countries: Does the Exchange Rate Regime Matter?, August 2002

760 Bruno S. Frey and Lars P. Feld, Deterrence and Morale in Taxation: An Empirical Analysis, August 2002

761 Lars Calmfors and Åsa Johansson, Nominal Wage Flexibility, Wage Indexation and Monetary Union, August 2002 